\title{
Characterization of Biofumigated Ralstonia solanacearum Cells Using Micro-Raman Spectroscopy and Electron Microscopy
}

\author{
Mathews L. Paret, Shiv K. Sharma, and Anne M. Alvarez
}

First author: Department of Plant and Environmental Protection Sciences (PEPS), University of Hawaii at Manoa, Honolulu 96822; second author: Hawaii Institute of Geophysics and Planetology, University of Hawaii at Manoa; and third author: PEPS, University of Hawaii at Manoa.

Current address of M. L. Paret: North Florida Research and Education Center, University of Florida, Quincy 32351.

Accepted for publication 22 August 2011.

\begin{abstract}
Paret, M. L., Sharma, S. K., and Alvarez, A. M. 2012. Characterization of biofumigated Ralstonia solanacearum cells using micro-Raman spectroscopy and electron microscopy. Phytopathology 102:105-113.

Essential oils of palmarosa, lemongrass, and eucalyptus have shown promise as biofumigants for control of the bacterial wilt disease of edible ginger (Zingiber officinale) caused by Ralstonia solanacearum race 4 in previous potting medium studies. Biochemical changes in $R$. solanacearum cells were evaluated with micro-Raman spectroscopy following treatment with essential oils at different concentrations $(0.04,0.07$, and $0.14 \%$ [ $\mathrm{vol} / \mathrm{vol}]$ of culture medium) and changes in cell structure were observed using electron microscopy. All treatments except palmarosa oil at $0.04 \%$ caused significant reductions in levels of amino acids, purine and pyrimidine bases of nucleic acids, carbohydrates, and lipids, as indicated by significant reduction in Raman peak heights at $621,1,003$,

1,158, and 1,172 $\mathrm{cm}^{-1}$ (tyrosine); $758 \mathrm{~cm}^{-1}$ (tryptophan); 725, 782, 1,337, and $1,578 \mathrm{~cm}^{-1}$ (adenine, cytosine plus uracil, adenine, and adenine plus guanine, respectively); $1,097 \mathrm{~cm}^{-1}$ (carbohydrates); and 1,127, 1,450, and $2,932 \mathrm{~cm}^{-1}$ (lipids) compared with untreated controls. Lemongrass oil treatments were the most effective in degrading cellular components. Scanning electron microscopy of palmarosa and lemongrass-oil-treated cells showed rupture of cell walls and cell debris but no degradation was noted for eucalyptus-oil-treated cells. Palmarosa- and lemongrass-oiltreated cells were positively stained with uranyl acetate when viewed by transmission electron microscopy whereas controls and eucalyptus-oiltreated cells were negatively stained, indicating that the cell membranes were intact. The viability of eucalyptus-oil-treated cells was confirmed by cell culture following treatment. Micro-Raman spectroscopy is a powerful tool which can be further employed to better understand effects of fumigants and other bactericides on bacterial cells.
\end{abstract} and 1,031 inverse centimeters $\left(\mathrm{cm}^{-1}\right)$ (phenylalanine); 643, 827, 852,
Ralstonia solanacearum causes severe bacterial wilt on many economically important crops, including tomato (Lycopersicon esculentum), banana (Musa spp.), potato (Solanum tuberosum), geranium (Pelargonium spp.), and ginger (Zingiber officinale), in tropical, subtropical, and temperate regions of the world (9). In Hawaii, bacterial wilt of ginger has caused extensive crop losses since 1993, at times causing complete destruction of ginger plantations (1). Methyl bromide, a broad-spectrum fumigant, has been successfully used for preplanting fumigation of ginger fields to reduce $R$. solanacearum populations $(10,15,30)$. However, its production and use is being curtailed by the United States Environmental Protection Agency and other regulatory agencies in many countries (29). Thus, there is an immediate need for identifying alternative fumigants that can be used for managing $R$. solanacearum by direct field application.

Essential oils are volatile oils extracted from various plants, which provide the basic aroma of the plant. Because of their antimicrobial properties, some oils have been studied as potential alternatives to methyl bromide fumigation. Palmarosa (Cymbopogon martini), lemongrass (C. citratus), tea tree (Melaleuca alternifolia), thyme (Thymus vulgaris), and wild marjoram (Origanum vulgare) oils have been previously evaluated as potential biofumigants in potting medium studies on a highly pathogenic

Corresponding author: A. M. Alvarez; E-mail address: alvarez@ hawaii.edu

* The $\boldsymbol{e}$-Xtra logo stands for "electronic extra" and indicates that the online version contains two supplemental figures.

http://dx.doi.org/10.1094/PHYTO-12-10-0330

(c) 2012 The American Phytopathological Society
$R$. solanacearum race 1 strain (25) which infects tomato in Florida. Similarly, effects of palmarosa, lemongrass, and eucalyptus (Eucalyptus globulus) oils on a representative $R$. solanacearum race 4 strain which infects edible ginger were evaluated by in vitro assays, epifluorescence microscopy, and survival studies in potting medium (24). In these assays, palmarosa and lemongrass oils significantly reduced $R$. solanacearum populations in heavily infested potting medium. Effects of these oils at the subcellular level, including biochemical or morphological analysis of the biofumigated cells, have not been previously reported.

Raman spectroscopy, based on the inelastic scattering of photons by molecules, is a vibrational spectroscopic technique that can provide detailed chemical composition of numerous molecules $(3,28)$. In Raman scattering, photons lose or gain energy during the scattering process, with a resultant increase or decrease in the wavelength, respectively $(3,7)$. The difference in energy between incident and Raman-scattered light (the Raman shift) is unique for individual molecules and is associated with the vibration of a particular chemical bond or a single functional group in the molecule (20).

Low sensitivity, interference with fluorescence background, and difficulty in data interpretation has hampered the use of Raman spectroscopy for diverse applications until the 1990s (13). Advances in laser technology, use of charge-coupled devices, and improved analysis methodologies over the last two decades have led to the development of stronger Raman signals providing high sensitivity to the technique, less background, and efficient computation, respectively. Significant modifications of the technique arrived with the combination of Raman spectroscopy with an 
optical microscope set-up for applications in single-cell bacterial analysis (26), now known as micro-Raman spectroscopy. Due to the ease of sample preparation and speed in obtaining results, this method is now being used more frequently for characterization of biological materials, including bacterial and algal cells $(5,11,14$, $20)$. Because the intensity of the Raman bands of a specific biomolecule corresponds to the number of vibrational modes of atomic nuclei (3), it can also be used for studying the changes in the patterns of specific molecules of interest. Micro-Raman spectroscopy is also a nondestructive method and requires only a small sample volume for analysis of microbial cells (5). Raman profiles of numerous plant-associated bacteria including $R$. solanacearum, are currently available (23).

The objectives of the current study were to (i) analyze the biochemical changes in $R$. solanacearum race 4 cells after treatments with palmarosa, lemongrass, and eucalyptus oils using microRaman spectroscopy; (ii) observe the direct effects of the treatments on the cells using electron microscopy; and (iii) evaluate the bactericidal effects of the treatments on the cells.

Lemongrass oil contains three major antimicrobial compounds (geranyl acetate, citral, and citronellal) which could damage bacterial cells. Palmarosa oil contains two of these antimicrobials (geranyl acetate and citronellal), and eucalyptus oil contains only eucalyptol. We hypothesize that a greater number of active compounds in a given oil will enhance its effectiveness as a biofumigant or bactericide, possibly due to increased activity on bacterial cells, and we explored the use of micro-Raman spectroscopy for this analysis.

\section{MATERIALS AND METHODS}

Bacterial strain. A well-characterized, representative strain of $R$. solanacearum race 4 (A4515) (35) isolated from edible ginger from the island of Hawaii was streaked onto nutrient agar (NA) (Bacto Nutrient Agar; Difco Laboratories, Detroit) with a plastic loop (to avoid interference from possible metallic contamination) and incubated at $28^{\circ} \mathrm{C}$ for 48 to $72 \mathrm{~h}$. Two to three colonies of each strain were picked from NA, transferred to $2 \mathrm{ml}$ of sterile distilled water $\left(\mathrm{dH}_{2} \mathrm{O}\right)$ in a test tube, vortexed for $10 \mathrm{~s}$, and adjusted spectrophotometrically to an optical density at $600 \mathrm{~nm}$ $\left(\mathrm{OD}_{600}\right)=0.1$ corresponding to $10^{8} \mathrm{CFU} / \mathrm{ml}$.

Plant essential oils. Essential oils of palmarosa, lemongrass, and eucalyptus (Camden-Grey Essential Oils Inc., Doral, FL) were tested at three concentrations $(0.04,0.07$, and $0.14 \%$ [vol/vol] of culture medium) in the current study. Two concentrations $(0.04$ and $0.07 \%$ [vol/vol] $)$ had been reported as effective for reducing bacterial wilt of tomato in Florida (25).

Sample preparation for micro-Raman spectroscopy. An in vitro vapor diffusion assay was used to treat $R$. solanacearum cells with the plant essential oils. Molten NA $(20 \mathrm{ml})$ was poured into petri plates and dried in a laminar flow hood for $20 \mathrm{~min}$. Once the agar solidified, the $R$. solanacearum strain $\left(0.1 \mathrm{ml} ; 10^{8}\right.$ $\mathrm{CFU} / \mathrm{ml}$ ) was pipetted onto the center of the plate, spread evenly over the entire surface with a sterile glass rod, and dried for $15 \mathrm{~min}$. Aliquots of the tested oils were added to the sterile absorbent cellulose filter disks (6 $\mathrm{mm}$ in diameter) (Whatman Schliecher \& Schuell, Keene, NH) to attain final concentrations of $0.04,0.07$, and $0.14 \%(\mathrm{vol} / \mathrm{vol})$ of the oil in the culture medium. The disks were placed on the lid of the petri plates and plates were sealed with Parafilm (Pechiney Plastic Packaging, Chicago) and incubated upside down for 48 to $72 \mathrm{~h}$ at $28^{\circ} \mathrm{C}$ in the dark. After the incubation period, the lids of the petri plates were removed to release the excess volatiles of the essential oils trapped in the petri plate. Sterile $\mathrm{dH}_{2} \mathrm{O}(10 \mathrm{ml})$ was pipetted onto each of the NA plates. A sterile glass rod was used to detach any growth of the bacterium on the medium and the samples were poured into 10-ml glass test tubes. The samples were vortexed for $20 \mathrm{~s}$, and 1-ml subsamples were centrifuged in a microcentrifuge at $16,000 \times g$ for $3 \mathrm{~min}$. The supernatants were discarded and the pellets resuspended in $1 \mathrm{ml}$ of $0.85 \% \mathrm{NaCl}$ followed by spinning the cells down. The cells were subsequently washed twice in $1 \mathrm{ml}$ of $\mathrm{dH}_{2} \mathrm{O}$ to remove any agar, and resuspended in $100 \mu \mathrm{l}$ sterile of $\mathrm{dH}_{2} \mathrm{O}$ for analysis using the micro-Raman spectroscope.

Micro-Raman instrumentation. Samples were excited by an Invictus 785-nm (near-infrared) laser and Raman spectra were measured with an optical fiber-coupled micro-Raman RXN system (Kaiser Optical Systems Inc., Ann Arbor, MI). A polished mirror aluminum sheet Anolux III (Anomet, Inc., Ontario, Canada) of 25 by $25 \mathrm{~mm}^{2}$ and $0.5 \mathrm{~mm}$ in thickness was used as the substrate $(19,37)$. The aluminum sheet substrate was cleaned with methanol, and $5 \mu \mathrm{l}$ of $R$. solanacearum samples were spotted for micro-Raman analysis. The samples were air dried at $25^{\circ} \mathrm{C}$ for 30 min before taking the spectra. The laser power at the sample was kept at $20 \mathrm{~mW}$ and the exposure time was $60 \mathrm{~s}$. An $\times 50$ objective was used for the Raman measurements. The thickness of the laser beam is $\approx 4$ to $5 \mu \mathrm{m}$ and the entire bacterial cell is within the excitation region.

Micro-Raman spectral analysis. The analysis of the spectra collected with the 785-nm laser excitation was carried out with GRAMS/AI software (Thermo Scientific, Waltham, MA). Five Raman spectra were taken for each sample followed by substrate subtraction, averaging, and baseline correction. All experiments were performed twice.

Sample preparation for electron microscopy. An in vitro disk diffusion assay was used for treating $R$. solanacearum cells with the tested plant essential oils for morphological analysis using scanning and transmission electron microscopy. Liquid NA $(20 \mathrm{ml})$ was poured into petri plates and dried for $20 \mathrm{~min}$ in a laminar flow hood. Once the agar solidified, $R$. solanacearum cells $\left(0.1 \mathrm{ml} ; 10^{8} \mathrm{CFU} / \mathrm{ml}\right)$ were pipetted onto the center of the plate and evenly spread over the entire surface with a sterile glass rod. The plates were dried for $15 \mathrm{~min}$. Aliquots of the tested oils were added to the 6-mm sterile absorbent filter disks at final concentrations of $0.04,0.07$, and $0.14 \%(\mathrm{vol} / \mathrm{vol})$ and placed at the center of the agar plate. The plates were incubated for 48 to $72 \mathrm{~h}$ at $28^{\circ} \mathrm{C}$. Untreated controls were incubated for the same duration. After the incubation period, the lids of the petri plate and the absorbent disks were removed. Using a sterile plastic loop, cells were transferred from the culture medium to $1 \mathrm{ml}$ of sterile $\mathrm{dH}_{2} \mathrm{O}$ in a $1.5-\mathrm{ml}$ microfuge tube. The samples were adjusted spectrophotometrically to $\mathrm{OD}_{600}=0.1\left(\approx 10^{8} \mathrm{CFU} / \mathrm{ml}\right)$. Cells were heat killed by placing the $1.5-\mathrm{ml}$ microfuge tube in a boiling water bath for 3 min.

Scanning electron microscopy. Essential-oil-treated $R$. solanacearum cells $\left(1 \mathrm{ml}\right.$ in $\mathrm{dH}_{2} \mathrm{O}$ of $\left.\mathrm{OD}_{600}=0.1\right)$ were trapped in a 13 -mm-diameter polycarbonate filter $(0.22 \mu \mathrm{m})$ attached to the tip of a sterile syringe. Trapped cells were fixed in $2.5 \%$ glutaraldehyde in $0.1 \mathrm{M}$ sodium cacodylate buffer $(1.0 \mathrm{ml}$ of $25 \%$ glutaraldehyde, $5.0 \mathrm{ml}$ of $0.2 \mathrm{M}$ sodium cacodylate buffer, and $4.0 \mathrm{ml}$ of $\mathrm{dH}_{2} \mathrm{O} ; \mathrm{pH} \mathrm{7.4)}$ for $1 \mathrm{~h}$ at $25^{\circ} \mathrm{C}$. Cells were washed twice in $0.1 \mathrm{M}$ sodium cacodylate buffer and post-fixed in $1 \%$ osmium tetroxide in $0.1 \mathrm{M}$ sodium cacodylate buffer for $1 \mathrm{~h}$ at $25^{\circ} \mathrm{C}$. The cells were dehydrated in graded ethanol series $(1 \mathrm{ml} ; 30,50,70$, 85 , and $95 \%$ ) with two changes every $5 \mathrm{~min}$. The filters were dried using a Samdri-795 critical point dryer (Tousimi, Rockville, MD) and then transferred onto stubs. Filters were fixed on the stubs using copper tape and silver stain. The stubs were sputter coated (Hummer 6.2; Anatech USA, Union City, CA) with gold palladium (8) for $2 \mathrm{~min}$. The cells were observed using a Hitachi S-800 field emission scanning electron microscope (SEM) (Hitachi High Technologies America Inc., Pleasanton, CA).

Transmission electron microscopy. Essential-oils-treated $R$. solanacearum cells $\left(4 \mu \mathrm{l}\right.$ in $\mathrm{dH}_{2} \mathrm{O}$ of $\left.\mathrm{OD}_{600}=0.1\right)$ in a $1.5-\mathrm{ml}$ microfuge sample were applied to a $\mathrm{Cu}$ grid (400-mesh) coated with Formvar, (polyvinyl formal) (Ted Pella Inc., Redding, CA) film and incubated at $25^{\circ} \mathrm{C}$ for $45 \mathrm{~s}$. The excess volume was 
wicked using a filter paper to leave a fine layer of cells on the grid. The samples were negatively stained with $4 \mu \mathrm{l}$ of $1 \%$ uranyl acetate for $15 \mathrm{~s}$ followed by removal of excess stain with a filter paper (22). The samples were subsequently washed with $4 \mu \mathrm{l}$ of sterile $\mathrm{dH}_{2} \mathrm{O}$ followed by immediate wicking off the extra sample, leaving a thin film. The samples were dried for 20 to $30 \mathrm{~min}$ at $25^{\circ} \mathrm{C}$ and the cells were observed using a transmission electron microscope (TEM) (Leo 912; Carl Zeiss MicroImaging, Inc., Thornwood, NY).

Experimental design and statistical analysis. The in vitro studies were set up in a completely randomized design, the Raman band intensities were studied using analysis of variance (ANOVA), and the means were compared using the StudentNewman-Keuls test $(P \leq 0.05)$. ANOVA was performed with SAS software (SAS version 9.1; SAS Institute Inc., Cary, NC).

\section{RESULTS}

Biochemical analysis of $\boldsymbol{R}$. solanacearum by micro-Raman spectroscopy. The spectrum of untreated $R$. solanacearum race 4 strain A4515 excited with the 785-nm laser in the region 500 to 1,800 inverse centimeters $\left(\mathrm{cm}^{-1}\right)$ was analyzed (Fig. 1) and bands were assigned based on published data (Table 1). The Raman intensities of the bands representing phenylalanine (Phe), tyrosine (Tyr), tryptophan (Trp), nucleic acid bases, carbohydrates, and lipids were studied after treatment with the plant essential oils
(Table 2; Fig. 2). Significant reductions in the Raman intensities of Phe bands at $621,1,003$, and $1,031 \mathrm{~cm}^{-1}(5,20)$ were observed in all the essential oil treatments except palmarosa oil at $0.04 \%$ compared with untreated controls (Table 2; Fig. 2). Eucalyptusoil-treated cells at all concentrations showed higher Raman intensities of Phe bands compared with that of cells treated with lemongrass oil at all concentrations and palmarosa oil at $0.14 \%$. The lemongrass-oil-treated cells had the weakest intensities of Phe bands among all the essential oils tested.

The Raman intensities of Tyr bands at 643, 827, 852, 1,158, and $1,172 \mathrm{~cm}^{-1}(5,6,20)$ showed significant differences between treatments (Table 2; Fig. 2). The intensities of the Tyr band at $643 \mathrm{~cm}^{-1}$ in cells treated with lemongrass oil at all concentrations were significantly lower than untreated $R$. solanacearum controls and other essential oil treatments except palmarosa oil at $0.04 \%$. In all the treatments except for palmarosa oil at $0.04 \%$, the intensities of "exposed" Tyr bands at $827 \mathrm{~cm}^{-1}$ were significantly reduced due to the treatments (Table 2; Fig. 2). The lowest intensities of the band were for cells treated with lemongrass oil at 0.07 and $0.14 \%$ and palmarosa oil at $0.14 \%$. Significant reductions in the intensities of bands in eucalyptus-oil-treated cells were noted at all concentrations compared with untreated controls. The intensities of "buried" Tyr bands at $852 \mathrm{~cm}^{-1}$ (6) were significantly lower for cells treated with lemongrass oil at all concentrations and palmarosa oil at 0.07 and $0.14 \%$ when compared with untreated control and eucalyptus-oil-treated cells.

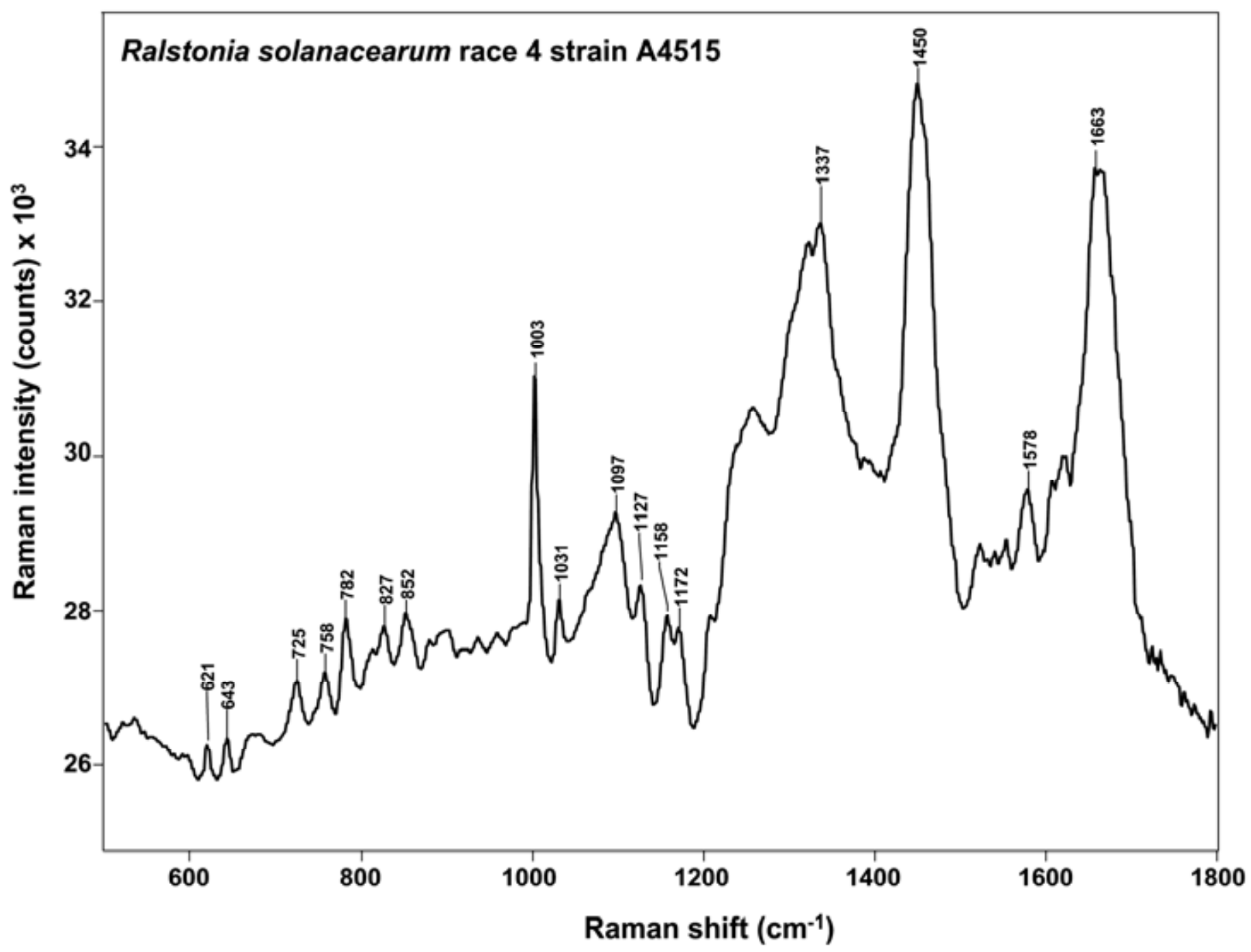

Fig. 1. Raman spectra of Ralstonia solanacearum race 4 strain A4515 excited with 785-nm laser. Data are averages of 10 spectra. Units used for expressing wave number in Raman spectra is inverse centimeters $\left(\mathrm{cm}^{-1}\right)$. 
Interestingly, consistent reductions in the intensities of the Tyr band at $1,158 \mathrm{~cm}^{-1}$ were seen for all the essential-oil-treated cells compared with untreated cells. The intensities of the Tyr band at $1,172 \mathrm{~cm}^{-1}$ also indicated the significant effect of lemongrass oil treatments at all concentrations and palmarosa oil at 0.07 and $0.14 \%$ on the cell compared with untreated cells. The intensity of the Trp band at $758 \mathrm{~cm}^{-1}(5,20)$ indicated a similar reduction in intensity as in the case of Phe and Tyr for treated and untreated cells.

The Raman intensities of bands representing nucleic acid bases showed reduction similar to that indicated in the analysis of the amino acids (Table 2; Fig. 2). The nucleic acid bases bands of adenine $(5,20)$ at $725 \mathrm{~cm}^{-1}$, cytosine combined with uracil (6) at $782 \mathrm{~cm}^{-1}$, adenine (32) at $1,337 \mathrm{~cm}^{-1}$, and adenine combined with guanine (32) at $1,578 \mathrm{~cm}^{-1}$ showed significantly reduced intensities in all the essential oil treatments except palmarosa oil at $0.04 \%$ compared with the untreated control. The intensities of adenine bands (725 and 1,337 $\mathrm{cm}^{-1}$ ) of cells treated with palmarosa oil at $0.04 \%$ and untreated controls were not significantly different. Lemongrass-oil-treated cells had the lowest intensity of nucleic acid bands followed by palmarosa-oil-treated cells at 0.07 and $0.14 \%$. No significant differences were noted between the intensities of the bands representing the combination of adenine and guanine in all lemongrass and eucalyptus oil treatments, and palmarosa-oil-treated cells at 0.07 and $0.14 \%$.

Raman intensities of bands representing carbohydrates (C-C, $\mathrm{C}-\mathrm{O}$, and $-\mathrm{C}-\mathrm{OH}$ deformation) at $1,097 \mathrm{~cm}^{-1}$ (18), =C-C $=$ unsaturated fatty acids of lipids at $1,127 \mathrm{~cm}^{-1}(31), \mathrm{CH}_{2}$ bending in lipids at $1,450 \mathrm{~cm}^{-1}(33)$, and $\mathrm{CH}_{2} / \mathrm{CH}_{3}$ stretching in lipids at $2,932 \mathrm{~cm}^{-1}(20,21)$ of the cells treated with lemongrass oil at $0.14 \%$ were lower compared with all other essential oil treatments (Table 2; Fig. 2). A Raman shift of 1 to $3 \mathrm{~cm}^{-1}$ is usually an acceptable tolerance for assignment of bands. However, for peaks associated with very broad areas, higher tolerance is permitted.

TABLE 1. Raman shift $\left(\mathrm{cm}^{-1}\right)$ and corresponding band assignments of Ralstonia solanacearum race 4 strain A4515 excited with the 785 -nm laser

\begin{tabular}{|c|c|c|}
\hline Raman shift $\left(\mathrm{cm}^{-1}\right)^{\mathrm{y}}$ & Assignments $^{\mathrm{z}}$ & References \\
\hline $621(\mathrm{~m})$ & Phenylalanine & 5,20 \\
\hline $643(\mathrm{~m})$ & Tyrosine & 5,20 \\
\hline $725(\mathrm{~m})$ & Adenine & 5,20 \\
\hline $758(\mathrm{~m})$ & Tryptophan & 5,20 \\
\hline $782(\mathrm{~m})$ & Cytosine + uracil & 6 \\
\hline $827(\mathrm{~m})$ & "Exposed" tyrosine & 6 \\
\hline $852(\mathrm{~m})$ & "Buried" tyrosine & 6 \\
\hline $1,003(\mathrm{~s})$ & Phenylalanine & 5,20 \\
\hline $1,031(\mathrm{~m})$ & Phenylalanine & 20 \\
\hline $1,097(\mathrm{~m}, \mathrm{bd})$ & Carbohydrates (C-C, C-O, -C-H deformation) & 18 \\
\hline $1,127(\mathrm{~m})$ & Lipids (=C-C = unsaturated fatty acids) & 31 \\
\hline $1,158(w)$ & Tyrosine & 20 \\
\hline $1,172(w)$ & Tyrosine & 20 \\
\hline $1,337(\mathrm{~s})$ & Adenine & 32 \\
\hline $1,450(\mathrm{~s})$ & Lipids $\left(\mathrm{CH}_{2}\right.$ bending $)$ & 33 \\
\hline $1,578(\mathrm{~m})$ & Adenine + guanine & 32 \\
\hline $1,663(\mathrm{~s})$ & Amide I & 6,20 \\
\hline $2,932(\mathrm{~s})$ & Lipids $\left(\mathrm{CH}_{3}\right.$ and $\mathrm{CH}_{2}$ stretching $)$ & 20,21 \\
\hline
\end{tabular}

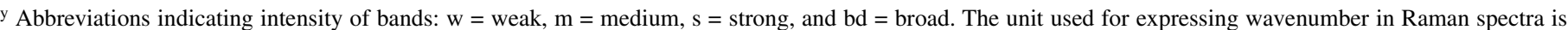
inverse centimeters $\left(\mathrm{cm}^{-1}\right)$.

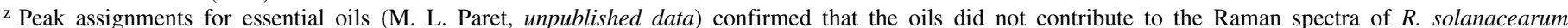
(lemongrass oil: geranyl acetate at $1,673 \mathrm{~cm}^{-1}$, citral at $1,630 \mathrm{~cm}^{-1}$, and citronellal at 1,382 $\mathrm{cm}^{-1}$; palmarosa oil: geranyl acetate at $1,673 \mathrm{~cm}^{-1}$ and citronellal at $1,382 \mathrm{~cm}^{-1}$; and eucalyptus oil: eucalyptol at $1,657 \mathrm{~cm}^{-1}$ and citronellal at $1,382 \mathrm{~cm}^{-1}$ ).

TABLE 2. Raman intensities of bands representing Ralstonia solanacearum race 4 strain A4515 treated with plant essential oils ${ }^{\mathrm{x}}$

\begin{tabular}{|c|c|c|c|c|c|c|c|c|c|c|c|}
\hline \multirow[b]{3}{*}{ Band assignments } & \multirow[b]{3}{*}{ Shift $\left(\mathrm{cm}^{-1}\right)^{\mathrm{y}}$} & \multicolumn{10}{|c|}{ Raman intensity of $R$. solanacearum cells treated with plant essential oils (\% vol/vol) ${ }^{\mathrm{z}}$} \\
\hline & & \multirow[b]{2}{*}{ Control } & \multicolumn{3}{|c|}{ Palmarosa oil } & \multicolumn{3}{|c|}{ Lemongrass oil } & \multicolumn{3}{|c|}{ Eucalyptus oil } \\
\hline & & & 0.04 & 0.07 & 0.14 & 0.04 & 0.07 & 0.14 & 0.04 & 0.07 & 0.14 \\
\hline \multirow[t]{3}{*}{ Phenylalanine } & 621 & $455.5 \mathrm{~b}$ & $509.7 \mathrm{a}$ & $229.1 \mathrm{~d}$ & $150.9 \mathrm{e}$ & $135.4 \mathrm{e}$ & $124.1 \mathrm{e}$ & $98.5 \mathrm{e}$ & $303.8 \mathrm{c}$ & $335.4 \mathrm{c}$ & $243.5 \mathrm{~d}$ \\
\hline & 1,003 & $3,412.6 \mathrm{a}$ & $4,052.0 \mathrm{~b}$ & $1,868.3 \mathrm{e}$ & $832.7 \mathrm{f}$ & $744.5 \mathrm{f}$ & $717.6 \mathrm{f}$ & $180.5 \mathrm{~g}$ & $2,605.0 \mathrm{c}$ & $2,530.4 \mathrm{c}$ & $2,064.1 \mathrm{~d}$ \\
\hline & 1,031 & $652.2 \mathrm{~b}$ & 739.7 a & $348.4 \mathrm{~d}$ & $175.8 \mathrm{e}$ & $129.3 \mathrm{e}$ & $152.9 \mathrm{e}$ & $26.2 \mathrm{f}$ & $522.3 \mathrm{c}$ & $533.3 \mathrm{c}$ & $351.4 \mathrm{~d}$ \\
\hline \multirow[t]{5}{*}{ Tyrosine } & 643 & $493.9 \mathrm{~b}$ & $651.0 \mathrm{a}$ & $327.4 \mathrm{~d}$ & $230.4 \mathrm{e}$ & $115.9 \mathrm{fg}$ & $141.5 \mathrm{f}$ & $75.4 \mathrm{~g}$ & $367.6 \mathrm{~cd}$ & $408.4 \mathrm{c}$ & $318.3 \mathrm{~d}$ \\
\hline & 827 & $450.6 \mathrm{~b}$ & $764.8 \mathrm{a}$ & $255.7 \mathrm{c}$ & $165.7 \mathrm{de}$ & $209.9 \mathrm{~cd}$ & $121.6 \mathrm{e}$ & $102.3 \mathrm{e}$ & $243.0 \mathrm{~cd}$ & $215.0 \mathrm{~cd}$ & $288.7 \mathrm{c}$ \\
\hline & 852 & $671.4 \mathrm{~b}$ & $748.4 \mathrm{a}$ & $234.1 \mathrm{e}$ & $52.1 \mathrm{f}$ & $85.6 \mathrm{f}$ & $87.8 \mathrm{f}$ & $51.1 \mathrm{f}$ & $446.5 \mathrm{c}$ & $334.0 \mathrm{~d}$ & $324.7 \mathrm{~d}$ \\
\hline & 1,158 & $630.9 \mathrm{a}$ & $14.8 \mathrm{c}$ & $32.1 \mathrm{bc}$ & $64.2 \mathrm{bc}$ & $96.2 \mathrm{~b}$ & $65.1 \mathrm{bc}$ & $86.5 \mathrm{bc}$ & $92.1 \mathrm{~b}$ & $51.9 \mathrm{bc}$ & $32.7 \mathrm{bc}$ \\
\hline & 1,172 & $519.9 \mathrm{bc}$ & $1,071.5 \mathrm{a}$ & $327.9 \mathrm{~d}$ & $205.3 \mathrm{e}$ & $76.7 \mathrm{e}$ & $127.6 \mathrm{e}$ & $119.4 \mathrm{e}$ & $600.4 \mathrm{e}$ & $442.4 \mathrm{~cd}$ & $464.9 \mathrm{bcd}$ \\
\hline Tryptophan & 758 & $569.4 \mathrm{~b}$ & $726.4 \mathrm{a}$ & $206.8 \mathrm{~d}$ & 88.7 e & $134.7 \mathrm{e}$ & $111.5 \mathrm{e}$ & $101.6 \mathrm{e}$ & $400.3 \mathrm{c}$ & $385.1 \mathrm{c}$ & $354.0 \mathrm{c}$ \\
\hline \multirow[t]{2}{*}{ Adenine } & 725 & $641.9 \mathrm{a}$ & $601.8 \mathrm{a}$ & $228.5 \mathrm{c}$ & $175.2 \mathrm{~cd}$ & $159.6 \mathrm{~cd}$ & $136.0 \mathrm{~d}$ & $145.9 \mathrm{~cd}$ & $369.3 \mathrm{~b}$ & $319.9 \mathrm{~b}$ & $193.5 \mathrm{~cd}$ \\
\hline & 1,337 & $861.8 \mathrm{a}$ & $998.7 \mathrm{a}$ & $378.4 \mathrm{bc}$ & $207.4 \mathrm{c}$ & $237.7 \mathrm{c}$ & $279.2 \mathrm{c}$ & $177.9 \mathrm{c}$ & $610.8 \mathrm{~b}$ & $393.3 \mathrm{bc}$ & $248.5 \mathrm{c}$ \\
\hline Adenine + guanine & 1,578 & $565.8 \mathrm{~b}$ & $1,048.1 \mathrm{a}$ & $183.7 \mathrm{c}$ & $231.9 \mathrm{c}$ & $195.4 \mathrm{c}$ & $255.2 \mathrm{c}$ & $221.1 \mathrm{c}$ & $359.5 \mathrm{c}$ & $300.4 \mathrm{c}$ & $212.6 \mathrm{c}$ \\
\hline Cytosine + uracil & 782 & $1,066.4 \mathrm{~b}$ & $1,174.1 \mathrm{a}$ & $384.5 \mathrm{e}$ & $88.0 \mathrm{f}$ & $173.4 \mathrm{f}$ & $108.5 \mathrm{f}$ & $104.7 \mathrm{f}$ & $725.4 \mathrm{c}$ & $511.4 \mathrm{~d}$ & $352.4 \mathrm{e}$ \\
\hline Carbohydrates & 1,097 & $759.0 \mathrm{~b}$ & $1,180.7 \mathrm{a}$ & $286.3 \mathrm{~cd}$ & $149.6 \mathrm{~cd}$ & $134.7 \mathrm{~cd}$ & $98.6 \mathrm{~cd}$ & $69.6 \mathrm{~d}$ & $401.1 \mathrm{c}$ & $264.6 \mathrm{~cd}$ & $230.9 \mathrm{~cd}$ \\
\hline \multirow[t]{3}{*}{ Lipids } & 1,127 & $877.5 \mathrm{~b}$ & $1,088.9 \mathrm{a}$ & $484.3 \mathrm{e}$ & $206.9 \mathrm{f}$ & $108.2 \mathrm{~g}$ & $182.0 \mathrm{fg}$ & $127.9 \mathrm{fg}$ & $717.1 \mathrm{c}$ & $706.0 \mathrm{c}$ & $608.1 \mathrm{~d}$ \\
\hline & 1,450 & $3773.8 \mathrm{~b}$ & $7,674.5 \mathrm{a}$ & $497.6 \mathrm{~d}$ & $402.9 \mathrm{~d}$ & $1,570.5 \mathrm{c}$ & $500.9 \mathrm{~d}$ & $188.1 \mathrm{~d}$ & $4,689.7 \mathrm{~b}$ & $3,756.0 \mathrm{~b}$ & $2,100.1 \mathrm{c}$ \\
\hline & 2,932 & $53,523.8 \mathrm{~b}$ & $73,394.1 \mathrm{a}$ & $21,808.2 \mathrm{f}$ & $5,384.2 \mathrm{~g}$ & $4,052.9 \mathrm{~g}$ & $5,432.1 \mathrm{~g}$ & $862.5 \mathrm{~g}$ & $38,807.8 \mathrm{c}$ & $32,375.3 \mathrm{c}$ & $27,447.0 \mathrm{e}$ \\
\hline Amide I & 1,663 & $609.8 \mathrm{~b}$ & $1,754.8 \mathrm{a}$ & $780.8 \mathrm{~b}$ & $331.1 \mathrm{~b}$ & $324.0 \mathrm{~b}$ & $359.3 \mathrm{~b}$ & $345.9 \mathrm{~b}$ & $558.3 \mathrm{~b}$ & $765.1 \mathrm{~b}$ & $649.6 \mathrm{~b}$ \\
\hline
\end{tabular}

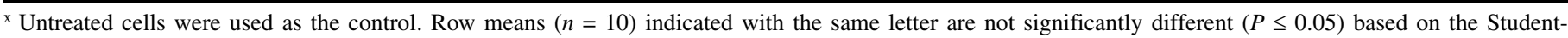
Newman-Keuls test.

y Raman shift in inverse centimeters $\left(\mathrm{cm}^{-1}\right)$.

z Percentage volume $(\% \mathrm{vol} / \mathrm{vol})$ of the essential oil in the culture medium. 
For example, a band at $1,097 \mathrm{~cm}^{-1}$ is a broad band and, thus, will have greater tolerance (4 to $6 \mathrm{~cm}^{-1}$ ). Lemongrass-oil-treated cells had the lipids band with the lowest intensity, followed by cells treated with palmarosa oil at 0.07 and $0.14 \%$. Amide I $(6,20)$ band intensities at $1,663 \mathrm{~cm}^{-1}$ were reduced by all the essential oil treatments except palmarosa oil at 0.04 and $0.07 \%$ and eucalyptus oil at 0.07 and $0.14 \%$ (Table 2; Fig. 2). Lemongrass-oil-treated cells had the lowest intensity of this band. It is possible to have interference from $\mathrm{C}=\mathrm{C}$ bands for the $1,663 \mathrm{~cm}^{-1}$ band. However, we have tentatively assigned this as the Amide I band based on this assignment on numerous Raman spectral analysis on bacterial cells $(6,20)$.

The Raman spectrum did not change uniformly due to the biofumigation with palmarosa oil. For example, although peaks of palmarosa-oil-treated cells at 725 and $1,337 \mathrm{~cm}^{-1}$ showed no significant changes following biofumigation (compare untreated control with palmarosa oil treatment at $0.04 \%$ ), peak intensities of several compounds (peaks 621, 1,003, 1,031, 643, 827, 852, and $1,172 \mathrm{~cm}^{-1}$, and so on) significantly increased when treated with the palmarosa oil at $0.04 \%$ compared with the untreated control. However, at higher concentrations of palmarosa oil (0.07 and $0.14 \%$ ), the peak intensities for oil-treated cells were significantly lower compared with the untreated control. In the case of lemongrass-oil-treated cells, the intensities of several compounds (peaks
$621,1,003,1,031,643,827,852,1,158$, and $1,172 \mathrm{~cm}^{-1}$, and so on) were consistently lower compared with the untreated cells, and this showed a concentration-dependent degradation. Eucalyptus oil caused the least effect in changing the biochemical properties, and this falls in line with the findings in our previous in vitro studies (24).

Characterization of the essential oils using micro Raman spectroscopy also confirmed that the essential oils did not contribute to the Raman spectra (Table 1) (lemongrass oil: geranyl acetate at $1,673 \mathrm{~cm}^{-1}$, citral at $1,630 \mathrm{~cm}^{-1}$, and citronellal at $1,382 \mathrm{~cm}^{-1}$; palmarosa oil: geranyl acetate at $1,673 \mathrm{~cm}^{-1}$ and citronellal at $1,382 \mathrm{~cm}^{-1}$; and eucalyptus oil: eucalyptol at $1,657 \mathrm{~cm}^{-1}$ and citronellal at $1,382 \mathrm{~cm}^{-1}$ ).

Morphological comparisons of $R$. solanacearum cells by scanning electron microscopy. As shown in SEM micrographs, healthy $R$. solanacearum cells were smooth textured (Fig. 3). Heat-killed cells were twisted in shape and bubble-like structures were noticed outside the cell. Cells treated with eucalyptus oils at all concentrations were sunken in appearance; at $0.14 \%$, a slimy material was attached to the cells but this material could not be confirmed as cell debris. Cell rupture and debris were not noted in any of the eucalyptus-oil-treated cells. Cells treated with palmarosa oil at all concentrations and lemongrass oil at 0.07 and $0.14 \%$ were ruptured. Large masses of debris were attached to the

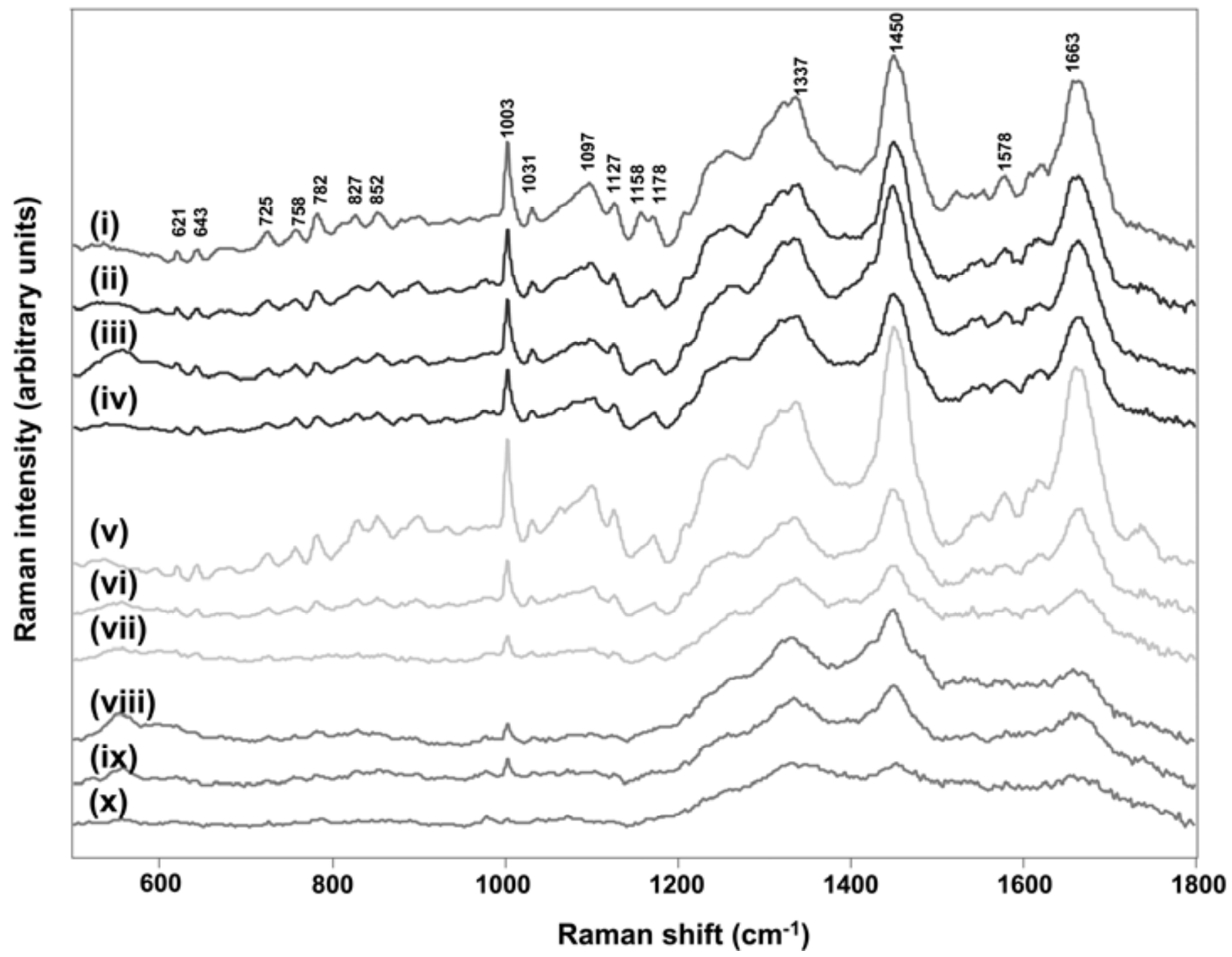

Fig. 2. Raman spectra of Ralstonia solanacearum race 4 strain A4515 treated with plant essential oils. i, Control-untreated cells; ii, iii, and iv, cells treated with eucalyptus oil at $0.04,0.07$, and $0.14 \%$ ( $\mathrm{vol} / \mathrm{vol}$ ) (volume of oil with respect to culture medium), respectively; v, vi, and vii, cells treated with palmarosa oil at $0.04,0.07$, and $0.14 \%(\mathrm{vol} / \mathrm{vol})$, respectively; and viii, ix, and x, cells treated with lemongrass oil at 0.04, 0.07, and $0.14 \%$ (vol/vol), respectively. Each line represents the average of 10 spectra. 
cells, as in the case of lemongrass oil treatment at $0.14 \%$. Three pictures were taken for each treatment using SEM, and all the pictures within a treatment showed a consistent pattern (Fig. 3; Supplemental Figure 1).
Morphological comparisons of $R$. solanacearum cells by transmission electron microscopy. Healthy $R$. solanacearum cells were negatively stained with uranyl acetate as observed in TEM micrographs (Fig. 4). The electron-dense uranyl acetate
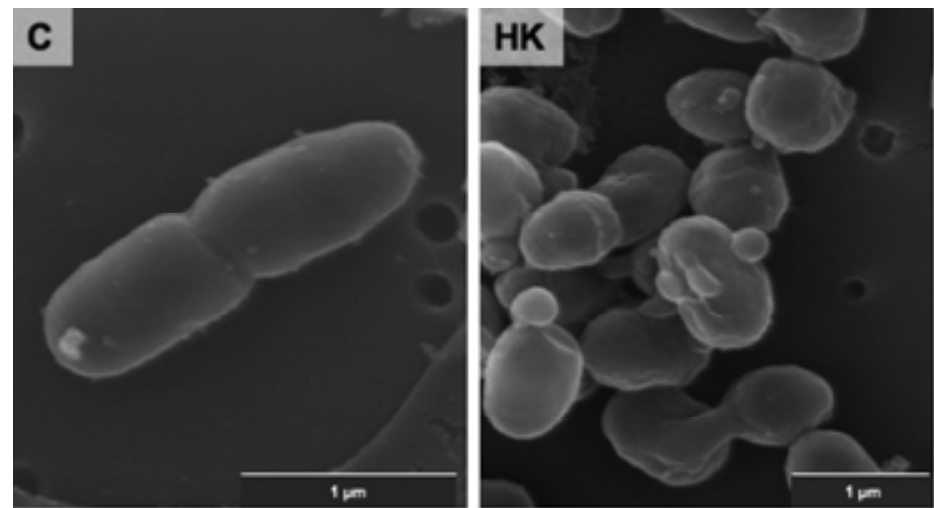

\section{Concentration of plant essential oils (\% vol $/ \mathrm{vol})$}

0.04
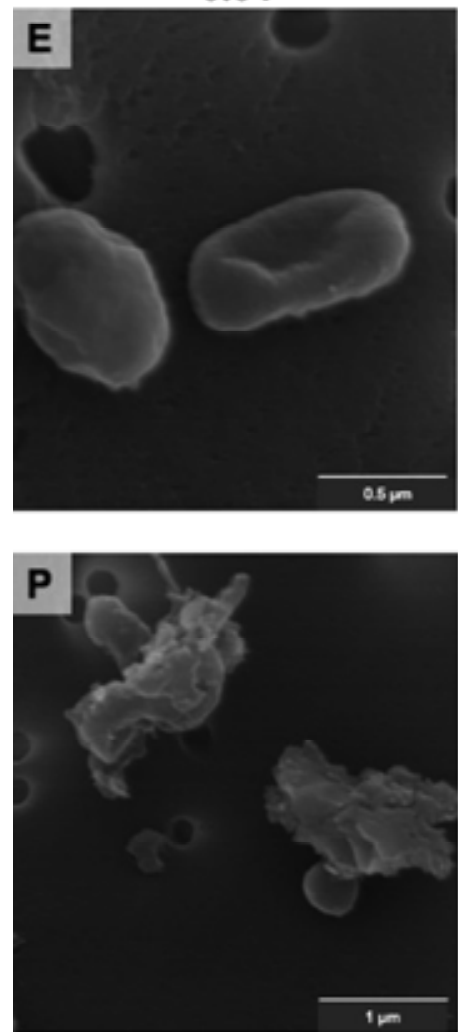

$1 \mathrm{pm}$

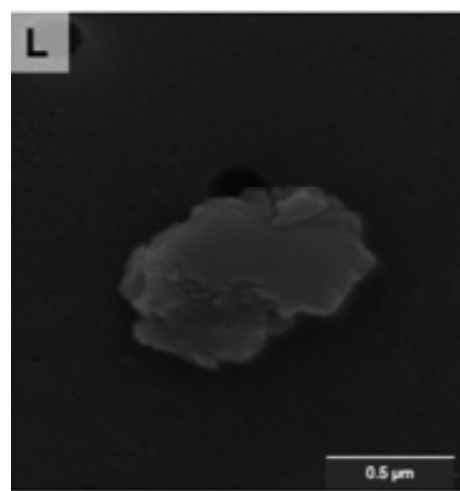

0.07
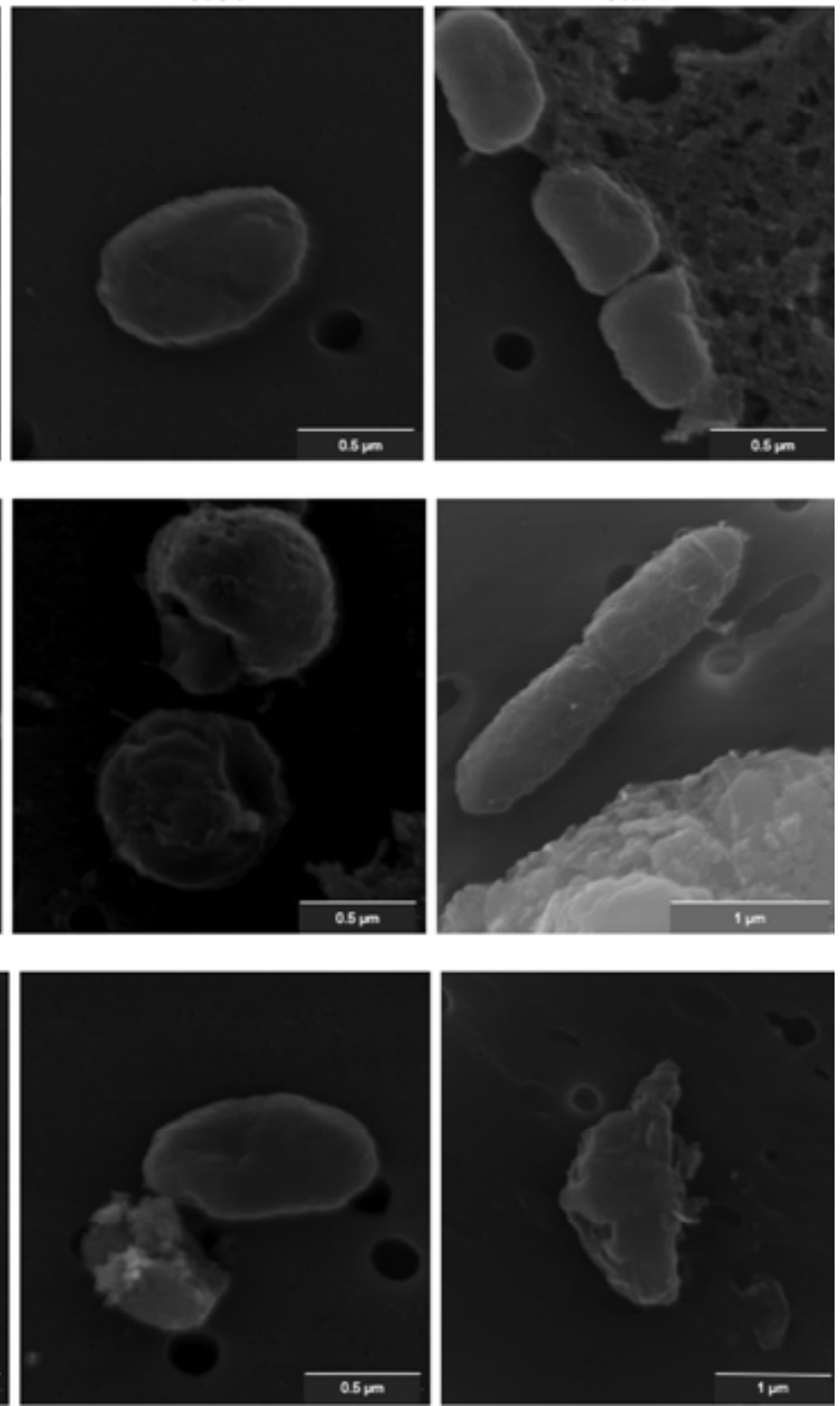

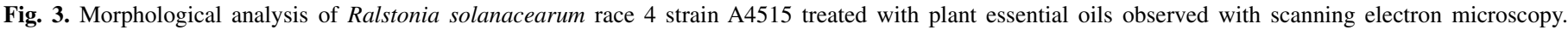

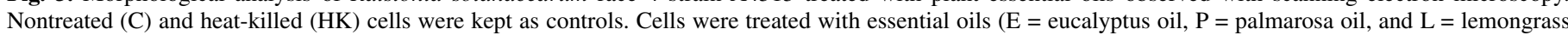
oil) at $0.04,0.07$, and $0.14 \%$ (vol/vol) (volume of oil with respect to culture medium) 
stain was bound to the cell surface rather than the cytoplasm, which indicated the integrity of the cell membrane of healthy cells. When heat killed, the cells ruptured, the stain penetrated the cell membrane, and the cells appeared completely dark. Thus, untreated and heat-killed cells served as two distinct controls for determining whether the cells were live or dead under the conditions (staining duration and procedure) of the experiment. Cells treated with eucalyptus oil at all concentrations were nega-
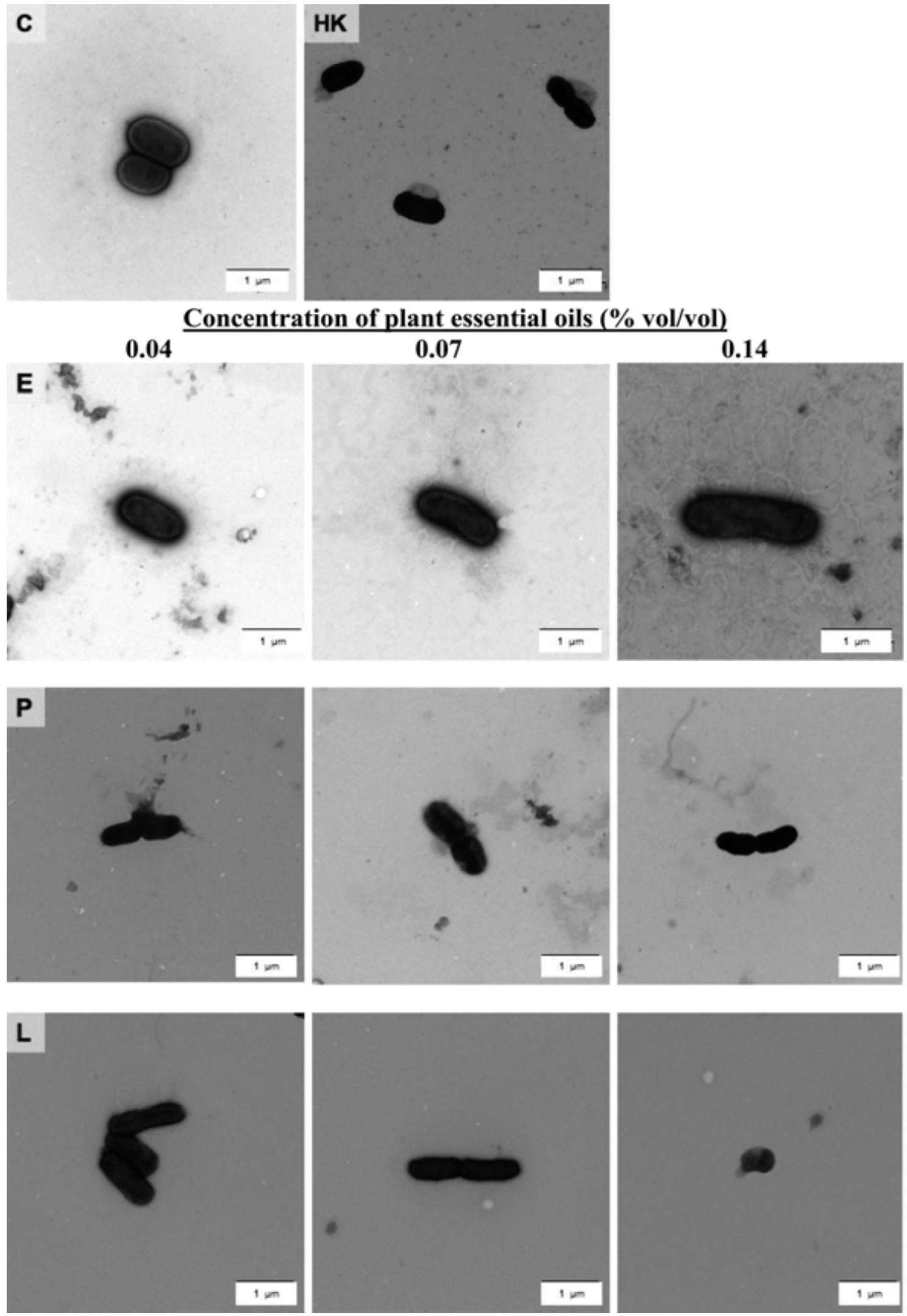

Fig. 4. Morphological analysis of Ralstonia solanacearum race 4 strain A4515 treated with plant essential oils observed with transmission electron microscopy. Nontreated $(\mathrm{C})$ and heat-killed $(\mathrm{HK})$ cells were kept as controls. Cells were treated with essential oils $(\mathrm{E}=$ eucalyptus oil, $\mathrm{P}=$ palmarosa oil, and $\mathrm{L}=$ lemongrass oil) at $0.04,0.07$, and $0.14 \%$ ( $\mathrm{vol} / \mathrm{vol})$ (volume of oil with respect to culture medium). 
tively stained, indicating no cell rupture. Cells at concentrations of 0.07 and $0.14 \%$ had a sunken appearance. Cells treated with palmarosa and lemongrass oils had compromised cell membrane, as indicated by positive staining with uranyl acetate. In addition, the cells did not have a smooth texture and were smaller in size compared with untreated controls. Three pictures were taken for each treatment using TEM, and all the pictures within a treatment showed a consistent pattern (Fig. 4; Supplemental Figure 2).

\section{DISCUSSION}

Biochemical analysis of bacteria and fungi using micro-Raman spectroscopy is a rapidly evolving area of research in applied spectroscopy $(5,6,18,21,31)$. Recently, Raman profiles of several diverse plant-pathogenic and plant-associated bacteria have been reported, and unique markers were identified for several genera of bacterial plant pathogens, including $R$. solanacearum (23). Here, we evaluated the degradative effects of various plant essential oils on cellular components of $R$. solanacearum, thereby inferring the biofumigant potential of the oils. Lemongrass oil was the most effective essential oil in this study, as indicated by significant reduction of intensities of bands of Phe, Tyr, Trp, nucleic acid bases, carbohydrates, lipids, and amide I. Lemongrass oil at all concentrations and palmarosa oil at $0.14 \%$ caused significant reduction of "buried" Tyr band at $852 \mathrm{~cm}^{-1}$ compared with untreated controls and other essential oil treatments, indicating its strong effects on the Tyr residues, which are buried in proteins (2). An observation unique to this study is that relative intensities of most of the bands except Tyr and adenine were higher than controls when cells were treated with palmarosa oil at $0.04 \%$. This may be due to the change in the binding of the molecules resulting in opening of the bacterial cell and greater signal emanating from the individual compound. Similar observations were noted for amino acid peaks in heat denaturation studies of Escherichia coli $(33,34)$. We also characterized the essential oils using micro-Raman spectroscopy, which confirmed that the essential oils did not contribute to the Raman spectra (M. L. Paret, unpublished data).

Previous studies have reported effects of essential oils and their active ingredients on plant pathogens in vitro followed by their application in pathogen-infested potting medium or field soil $(16,17,25)$. Pathogen survival and plant health after treatment with essential oils was also determined in these and other studies on $R$. solanacearum race 4 infecting edible ginger (22). The oils showed bactericidal and bacteriostatic ability based on the enumeration of live cells in culture media, live-dead cell staining, and observation using epifluorescence microscopy. Application of essential oils to potting medium inoculated with $R$. solanacearum resulted in lower infection rates and improved plant survival following treatment (22). The current study represents the first attempt by any group to characterize the properties of treated cells and forms the basis for future studies to elucidate the specific mode of action of these essential oils. Membrane potential studies in combination with micro-Raman spectroscopic studies have been previously used to study the mechanism of action of certain toxic compounds on E. coli and demonstrated the interaction of the test compounds with an artificial bilayer lipidic membrane, leading to local depolarization $(4,27,36)$. These and similar methods, in combination with micro-Raman spectroscopy, should help elucidate the mechanisms which give bactericidal properties to these oils.

Micrographs of the treated and untreated cells observed by SEM showed that the fumigated (essential-oil-treated) cells had a degraded appearance, indicating a direct effect on cell structure, but could not distinguish live from dead cells. However, complementary tests with TEM using a uranyl acetate staining procedure showed that the cell membrane was compromised, a further indication of bactericidal properties of lemongrass and palmarosa oils. The cytoplasm of damaged cells was dense and black whereas undamaged cells showed the typical negative stain around the cell membrane but not within the cell. Our previous studies using in vitro vapor diffusion assays have shown that $R$. solanacearum cells treated with eucalyptus oil at 0.04 and $0.07 \%$ grow on plates showing no inhibition zones whereas, when treated with $0.14 \%$, a very small inhibition zone was observed (22). Viable cells were cultured from these zones, indicating that eucalyptus oil was only bacteriostatic (24). In contrast, palmarosa- and lemongrass-oiltreated cultures failed to grow after treatment. These observations, plus findings from the live-dead cell-staining studies using epifluorescence microscopy (24) and the current observations from TEM micrographs, demonstrate the bactericidal properties of palmarosa and lemongrass oils at all concentrations, whereas eucalyptus oil at 0.04 and $0.07 \%$ had no effect on viability of $R$. solanacearum and, at $0.14 \%$, growth was inconsistent, sometimes showing a slight effect depending on the method used (22).

Micro-Raman studies on the oils have confirmed the identity of major antimicrobial components (M. L. Paret, unpublished data). In this current study, the data showed that lemongrass oil, which contained the greatest number of antimicrobials, was more effective in degrading $R$. solanacearum cells compared with palmarosa and eucalyptus oils, which had fewer active compounds. This further supports the findings from our previous in vitro studies (22).

A major limitation in applying essential oils to the field has been the large quantity required and the exorbitant price of these oils in the U.S. market. If active ingredients in these oils were synthesized, their biofumigant potential and cost-effectiveness could be evaluated. This approach was taken when thymol, the active ingredient in T. vulgaris, was tested for control of bacterial wilt on tomato (16). Use of active ingredients as soil fumigants through the drip system would require the product at $\approx 70$ to $100 \mathrm{~kg} / \mathrm{ha}$ (17), resulting in a cost of $\$ 1,000$ to $1,500 / \mathrm{ha}$, which is commercially viable. Further studies to understand the mode of action of the essential oils and their active ingredients are important for the final labeling of a marketable product for management of bacterial diseases on crops.

Micro-Raman spectroscopy, a tool often used in physics and chemistry, is increasingly being used by biologists for characterization of microorganisms. Biological applications include singlecell bacterial characterization reflecting metabolic status and growth history, and culture-independent studies on the function and physiology of unculturable microorganisms in the ecosystem using a combination of Raman microspectroscopy with isotope probing, fluorescent in situ hybridization, and optical tweezers $(12,13)$. Raman spectroscopy provides plant pathologists with a new tool to gain a better understanding of the effects of biologically active compounds on plant pathogens, and the complex biomolecular interactions of bacterial cells with their environment.

\section{ACKNOWLEDGMENTS}

The project was partially funded by the United States Department of Agriculture (USDA) Special Grants program for Tropical and Subtropical Agricultural Research (award number 2004-34135-15191) and USDA Agricultural Research Service Minor Crops Research (award number 59-5320-1-525). The Raman instrument used in the present work was funded under a cooperative agreement (WA11MF-07-2-0002) with the Army Research Laboratory. This is a joint contribution from CTAHR, SOEST (contribution number 8164), and HIGP (contribution number 1889). We thank A. K. Misra and T. Acosta for their valuable help in setting up Raman experiments and T. Carvalho for assistance and advice at the Biological Electron Microscope Facility at the University of Hawaii.

\section{LITERATURE CITED}

1. Alvarez, A. M., Trotter, K. J., Swafford, M. B., Berestecky, J. M., Yu, Q., Ming R., Hepperly, P. R., and Zee, F. 2005. Characterization and detection of Ralstonia solanacearum strains causing bacterial wilt of ginger in 
Hawaii. In: Bacterial Wilt The Disease and the Ralstonia solanacearum Species Complex. C. Allen, P. Prior, and A. C. Hayward, eds. American Phytopathological Society, St. Paul, MN.

2. Burstein, Y., and Patchornik, A. 1972. Use of a nonenzymatic cleavage reaction for the identification of exposed tyrosine residues in bovine pancreatic ribonuclease. Biochemistry 11:2932-2944.

3. Colthup, N. B., Daly, L. H., and Wiberley, S. E. 1990. Introduction to Infrared and Raman Spectroscopy, 3rd ed. Academic Press, Inc., San Diego, CA.

4. Daniel, P., Picart, P., Bendriaa, L., Sockalingum, G. D., Adt, I., Charrier, T., Durand, M. J., Ergan, F., Manfait, M., and Thouand, G. 2008. Effect of toxic organotin compounds on bacteria investigated by micro-Raman spectroscopy. Spectrosc. Lett. 41:19-28.

5. De Gelder, J., Gussem, K. D., Vandenabeele, P., and Moens, L. 2007. Reference database of Raman spectra of biological molecules. J. Raman Spectrosc. 38:1133-1147.

6. De Gelder, J., Gussem, K. D., Vandenabeele, P., Vancanneyt, M., Vos, P. D., and Moens, L. 2007. Methods for extracting biochemical information from bacterial Raman spectra: Focus on a group of structurally similar bio-molecules - fatty acids. Anal. Chim. Acta. 603:167-175.

7. Department of Material Science and Metallurgy, University of Cambridge. 2007. http://www.doitpoms.ac.uk/tlplib/raman/index.php.

8. Greif, D., Wesner, D., Regtmeir, J., and Anselmetti, D. 2010. High resolution imaging of surface patterns of single bacterial cells. Ultramicroscopy 110:1290-1296.

9. Hayward, A. C. 1991. The hosts of Pseudomonas solanacearum. In: Bacterial Wilt: The Disease and its Causative Agent Pseudomonas solanacearum. A. C. Hayward and G. L. Hartman, eds. CAB International, Wallingford, UK.

10. Hepperly, P., Zee, F., Kai, R., Arakawa, C., Meisner, M., Kratky, B., Hamamoto, K., and Sato, D. 2004. Producing bacterial wilt-free ginger in greenhouse culture. Coop. Ext. Serv. Coll. Trop. Agric. Hum. Resour. Univ. Hawaii Manoa. Soil Crop Manage. 8:1-6.

11. Heraud P., Beardall J., McNaughton D., and Wood B. R. 2007. In vivo prediction of the nutrient status of individual microalgal cells using Raman microspectroscopy. FEMS Microbiol. Lett. 275:24-30.

12. Huang, W. E., Bailey, M. J., Thompson, I. P., Whiteley, A. S., and Spiers, A. J. 2007. Single-cell Raman spectral profiles of Pseudomonas fluorescens SBW25 reflects in vitro and in planta metabolic history. Microbiol. Ecol. 53:414-425.

13. Huang, W. E., Li, M., Jarvis, R. M., Goodacre, R., and Banwart, S. A. 2010. Shining light on the microbial world: The application of Raman microspectoscopy. In: Advances in Applied Microbiology. A. I. Laskin, S. Sariaslani, and G. M. Gadd, eds. Elsevier Inc., San Diego, CA.

14. Huang, Y. Y., Beal, C. M., Cai, W. W., Ruoff, R. S., and Terentjev, E. 2010. Micro-Raman spectroscopy of algae: Composition analysis and fluorescence background behavior. Biotechnol. Bioeng. 105:889-898.

15. Ishii, M., and Aragaki, M. 1963. Ginger wilt caused by Pseudomonas solanacearum E. F. Smith. Plant Dis. Rep. 47:710-713.

16. Ji, P., Momol, M. T., Olson, S. M., Pradhanang, P. M., and Jones, J. B. 2005. Evaluation of thymol as biofumigant for control of bacterial wilt of tomato under field conditions. Plant Dis. 89:497-500.

17. Ji, P., Momol, M. T., Rich, J. R., Olson, S. M., and Jones, J. B. 2007. Development of an integrated approach for managing bacterial wilt and root knot on tomato under field conditions. Plant Dis. 91:1321-1326.

18. Lauks, M .L., Sengupta, A., Junge, K., Davis, E. J., and Swanson, B. D. 2005. Comparison of psychro-active arctic marine bacteria and common mesophillic bacteria using surface-enhanced Raman spectroscopy. Appl. Spectrosc. 59:1222-1228.

19. Misra, A. K., Sharma, S. K., Kamemoto, L., Zinin, P. V., Yu, Q., Hu, N., and Melnick, L. 2009. Novel micro-cavity substrates for improving the
Raman signal from submicrometer size materials. Appl. Spectrosc. 63:373-377.

20. Movasaghi, Z., Rehman, S., and Rehman, I. U. 2007. Raman spectroscopy of biological tissues. Appl. Spectrosc. Rev. 42:493-541.

21. Neugebauer, U., Schmid, U., Baumann, K., Ziebuhr, W., Kozitskaya, S., Deckert, V., Schmitt, M., and Popp, J. 2007. Towards a detailed understanding of the bacterial metabolism- spectroscopic characterization of Staphylococcus epidermis. ChemPhysChem 8:124-137.

22. Paret, M. L. 2009. Management of bacterial wilt of ginger (Zingiber officinale R.) caused by Ralstonia solanacearum with plant essential oils. Ph.D. dissertation, Department of Plant and Environmental Protection Sciences, College of Tropical Agriculture and Human Resources, University of Hawaii at Manoa, Honolulu.

23. Paret, M. L., Green, L. M., Sharma, S. K., and Alvarez, A. M. 2010. Biochemical characterization of Gram- positive and Gram-negative plantassociated bacteria by micro-Raman spectroscopy. Appl. Spectrosc. 64:433-441.

24. Paret, M. L., Kratky, B. A., and Alvarez, A. M. 2010. Effect of plant essential oils on Ralstonia solanacearum race 4 and bacterial wilt of edible ginger. Plant Dis. 94:521-527.

25. Pradhanang, P. M., Momol, M. T., Olson, S. M., and Jones, J. B. 2003. Effects of plant essential oils on Ralstonia solanacearum population density and bacterial wilt incidence in tomato. Plant Dis. 87:423-427.

26. Puppels, G. J., Demul, F. F. M., Otto, C., Greve, J., Robertnicoud, M., Arndtjovin, D. J., and Jovin, T. M. 1990. Studying single living cells and chromosomes by confocal Raman microspectoscopy. Nature 347:301303.

27. Radecka, H., Zielinska, D., and Radecki, J. 1999. Interaction of organic derivatives of tin (IV) and lead (IV) with model lipid membranes. Sci. Total Environ. 234:147-153

28. Raman, C. V. 1928. A change in wavelength in light scattering. Nature 121:619.

29. Rosskopf, E. N., Chellemi, D. O., Kokalis-Burelle, N., and Church, G. T. 2005. Alternatives to methyl bromide: A Florida perspective. APSnet feature story June 2005. Online publication

30. Sato, D. 1999. Reducing methyl bromide in pre-plant soil treatment for ginger root. Pages 1-3 in: Annu. Int. Res. Conf. Methyl Bromide Alt. Emissions Reductions. San Diego, CA.

31. Schuster, K. C., Urlaub, E., and Gapes, J. R. 2000. Single-cell analysis of bacteria by Raman microscopy: Spectral information on the chemical composition of the cells and heterogeneity in a culture. J. Microbiol. Methods 42:29-38.

32. Wu, Q., Hamilton, T., Nelson, W. H., Elliott, S., Sperry, J. F., and Wu, M. 2001. UV Raman spectral intensities of E. Coli and other bacteria excited at 228.9, 244.0, and 248.2 nm. Anal. Chem. 73:3432-3440.

33. Xie, C., and Li, Y. 2003. Confocal micro-Raman spectroscopy of single biological cells using optical trapping and shifted excitation difference techniques. J. Appl. Physiol. 93:2982-2986.

34. Xie, C., Li, Y., Tang, W., and Newton, R. J. 2003. Study of dynamic process of heat denaturation in optically trapped single micro-organisms by near-infrared Raman spectroscopy. J. Appl. Physiol. 94:6138-6242

35. Yu, Q., Alvarez, A. M., Moore, P. H., Zee, F., Kim, M. S., deSilva, A. S., Hepperly, P. R., and Ming, R. 2003. Molecular diversity of Ralstonia solanacearum isolated from ginger in Hawaii. Phytopathology 93:11241130.

36. Zielinska, D., Radecka, H., and Radecki, J. 2000. Contribution of membrane surface charge in the interaction of lead and tin derivatives with model lipid membranes. Chemosphere 40:327-330.

37. Zinin, P. V., Misra, A., Kamemoto, L., Yu, Q., and Sharma, S. K. 2007. Emulated transmission in confocal Raman microscopy. J. Opt. Soc. Am. B. 24:2779-2783. 